\title{
Merrifield resin-linked polyazole-based sorbent for heavy metal ions extraction from water
}

\author{
I.M.Zviagin ${ }^{1}$, S.V.Khimchenko ${ }^{1}$, T.A.Blank ${ }^{1}$, \\ I.B.-Kh.Shcherbakov ${ }^{1}$, E.Yu.Bryleva ${ }^{1}, Z . Y u . B u n i n a$,

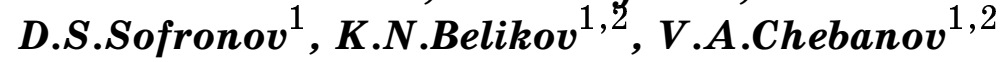 \\ ${ }^{1}$ SSI "Institute for Single Crystals", National Academy of Sciences of Ukraine, \\ 60 Nauky Ave., 61072 Kharkiv, Ukraine \\ ${ }^{2}$ V.Karazin Kharkiv National University, 4 Svobody Sq., \\ 61022 Kharkiv, Ukraine
}

Received September 18, 2018

\begin{abstract}
A new sorbent for heavy metal ions, that contains links with fragments of 1,2,3-triazole, 1,2,3- and 1,2,4-triazole, both triazoles and tetrazole was developed and appropriate procedures for the synthesis of these links were described. The obtained polymer is able to form stable complexes with the ions of heavy metals, such as $\mathrm{Eu}(\mathrm{III}), \mathrm{Cd}(\mathrm{II}), \mathrm{Pb}(\mathrm{II}), \mathrm{Cu}(\mathrm{II})$, $\mathrm{Sr}(\mathrm{II})$. The extraction rate dependence on the age of the sorbent, concentration of the cations, $\mathrm{pH}$, and concentration of competing anions was studied.

Keywords: click reaction, extraction rate, heavy metal ion sorption, Merrifield resin, solid carrier chemical modification.

Разработан сорбент для ионов тяжелых металлов, который содержит звенья с 1,2,3триазольным, 1,2,3- и 1,2,4-триазольными, и обоими триазольными и тетразольным фрагментами, ковалентно привитыми к поверхности смолы Меррифильда. Описаны методики синтеза звеньев с изучаемыми полиазолами. Полученный модифицированный полимер способен образовывать стабильные комплексы с ионами тяжелых металлов, такими как $\mathrm{Eu}(\mathrm{III}), \mathrm{Cd}(\mathrm{II}), \mathrm{Pb}(\mathrm{II}), \mathrm{Cu}(\mathrm{II}), \mathrm{Sr}(\mathrm{II})$. Изучена зависимость степени извлечения катионов этих металлов от возраста сорбента, концентрации катионов, pH, концентрации конкурирующих анионов.
\end{abstract}

Привитий до смоли Меррифільда сорбент на основі поліазолів для екстракції іонів важких металів із води. Є.М.Звягін, С.В.Хімченко, Т.А.Бланк, І.Б-Х.Щербаков, К.Ю.Брильова, З.Ю.Бунина, Д.С.Софронов, К.М.Беліков, В.А.Чебанов.

Розроблено сорбент для іонів важких металів, який містить ланки з 1,2,3-триазольним, 1,2,3- та 1,2,4-триазольними, та обома триазольними і тетразольним фрагментами, що ковалентно привиті до поверхні смоли Меррифільда. Описано методики синтезу ланок з поліазолами, що вивчаються. Отриманий модифікований полімер здатний утворювати стабільні комплекси з іонами важких металів, такими як $\mathrm{Eu}(\mathrm{III}), \mathrm{Cd}(\mathrm{II}), \mathrm{Pb}(\mathrm{II})$, $\mathrm{Cu}(\mathrm{II}), \mathrm{Sr}(\mathrm{II})$. Вивчено залежність ступіню вилучення катіонів цих металів від віку сорбенту, концентрації катіонів, рН, та концентрації конкуруючих аніонів.

\section{Introduction}

1,2,3-Triazoles, 1,2,4-triazoles, tetrazoles and other poly-nitrogen containing heterocycles are known for their ability to form stable complexes with metal ions
[1-4], especially $d$-block and $f$-block metals. Many of those polyazoles are electron-rich heterocycles and contain $s p^{2}$-hybridized nitrogen atoms with a lone pair not involved in sustaining aromaticity of the cycle. Such compounds can play the role of Lewis bases 
and have strong bonding to hard Lewis acids like multiple charge heavy metal ions. Two or more polyazole fragments that are present in one molecule potentially have even larger complexing ability per a unit of amount of matter $[5,6]$. Such reactive ligands can be covalently linked to the surface of a solid material and further used for extraction of metal ions from natural waters for the purpose of content monitoring and water purification [7].

Merrifield resin (poly( $p$-chloromethyl)styrene) is a perfect example of such a solid carrier [8,9], which can be covalently modified by the introduction of polyazole fragments. The resin is relatively affordable and widely used, non-toxic, and insoluble in most solvents including water.

The chlorine atom in chloromethyl fragment of Merrifield resin is easily substituted by other nucleophiles including azide group [10]. The azide-modified resin can be used to introduce consequentially different polyazole moieties to the polymer. One of the most popular methods for azide functionalization is copper-catalyzed 1,3-dipolar $[3+2]$ cycloaddition of azide to terminal alkyne [11]. 1,2,4-Triazole, among all other procedures, is obtained in the reaction of carboxylic acids and aminoguanidine [12]. It's crucial to mention the latter method is used for the preparation of 3-amino-1,2,4triazoles, and the amino group in position 3 can be transformed to a tetrazole cycle following the Gaponik procedure [13].

\section{Experimental}

\subsection{General}

The residual concentration of the target metal ions in the solutions after sorption was determined by atomic emission spectroscopy with inductively coupled plasma (AES-ICP) on the spectrometer TRACE SCAN Advantage (Thermo Jarrell Ash, USA). X-ray fluorescence analyses were performed on the Elvax Light spectrometer (Elvatech, Ukraine). IR spectra were obtained using the Fourier spectrophotometer SPECTRUM ONE (PerkinElmer) with KBr tablets. The solution $\mathrm{pH}$ was measured using the $\mathrm{pH}$ OHAUS STARTER 3100 pH meter (OHAUS, USA). Solutions were stirred with a magnetic stirrer MS300 (ULAB, PRC).

All chemicals and solvents used for synthesis, photometric measurements, and adsorbent properties study were of analytical reagent grade and used without further purification unless otherwise specified.

Merrifield Peptide Resin (particle size 100-200 mesh) came from Sigma-Aldrich.

The metal ions studied were $\mathrm{Eu}(\mathrm{III})$, $\mathrm{Cd}(\mathrm{II}), \mathrm{Pb}(\mathrm{II}), \mathrm{Cu}(\mathrm{II}), \mathrm{Sr}(\mathrm{II})$. $\mathrm{Eu}(\mathrm{III})$ has been used as a sample being chemically identical to ${ }^{241} \mathrm{Am}$. The stock standard solutions with the concentration $1 \mathrm{mg} \cdot \mathrm{L}^{-1}$ were prepared with ultrapure water obtained on a "P.NIX POWER SYSTEM" ("HUMAN CORPORATION", South Korea) from standard $1000 \mathrm{mg} \cdot \mathrm{L}^{-1}$ solutions (Sigma-Aldrich) and the $\mathrm{pH}$ level was adjusted using $0.25 \%$ aqueous ammonia solution.

Filter paper, ashless, Grade 589/2 white ribbon came from Sigma-Aldrich.

2.2. Preparation of 1,2,3-triazolyl-1,2,4triazolyltetrazole bonded to Merrifield resin

The sorbent was prepared in 4 reaction steps following the scheme in Fig. 1.

Step 1

$5 \mathrm{~g}(\max 32.8 \mathrm{mmol}$ of $\mathrm{Cl})$ of Merrifield resin 1 was suspended in $45 \mathrm{~mL}$ of DMF and $5 \mathrm{~g}$ (76.9 mmol) of sodium azide was added. The reaction mixture was mixed in a water bath for $24 \mathrm{~h}$ and then filtered and washed with an excess of water. The white solid product was dried in the air.

Step 2

$5.075 \mathrm{~g}\left(\max 31.9 \mathrm{mmol}\right.$ of $\mathrm{N}_{3}$ group) of the product obtained in step 1 was suspended in $30 \mathrm{~mL}$ of DMF and $2 \mathrm{~mL}(2.26 \mathrm{~g}$, $32.3 \mathrm{mmol}$ ) of propiolic acid, $1.22 \mathrm{~g}$ (6.4 mmol, $20 \mathrm{~mol} \%$ ) Cul and $2.76 \mathrm{~g}$ (12.8 mmol, $40 \mathrm{~mol} \mathrm{\% )} \mathrm{of} \mathrm{sodium} \mathrm{ascorbate}$ monohydrate were added. The reaction mix-

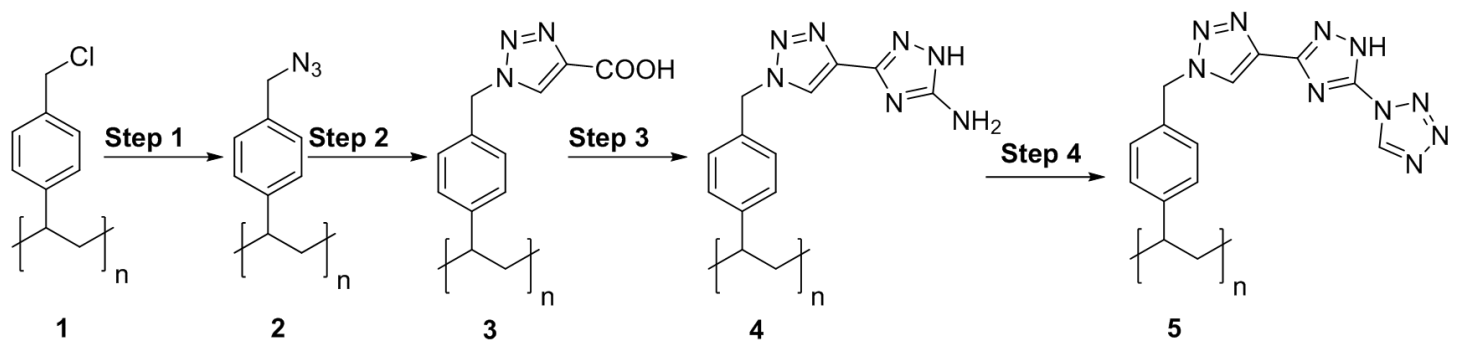

Fig. 1. Scheme of the sorbent preparation. 
ture was heated and mixed at $60^{\circ} \mathrm{C}$ for $24 \mathrm{~h}$. The reddish solid product was filtered off, washed with an excess of water, $50 \mathrm{~mL}$ of $\mathrm{AcOH}-\mathrm{H}_{2} \mathrm{O}(1: 1$ vol.) mixture and then again with water. The precipitate was then placed into $30 \mathrm{~mL}$ of $30 \% \mathrm{HNO}_{3}$ to dissolve the excess of elemental copper, then filtered off again, washed with an excess of water and placed to $30 \mathrm{~mL}$ of $1 \mathrm{M}$ $\mathrm{Na}_{2} \mathrm{H}_{2}$ EDTA solution. After vigorous stirring for $1 \mathrm{~h}$, the yellowish-white precipitate was filtered off and dried in the air.

Step 3

$2.8 \mathrm{~g}(\max 12.2 \mathrm{mmol}$ of $\mathrm{COOH}$ group) of step 2 product was mixed with $15 \mathrm{~mL}$ of thionyl chloride $(24.6 \mathrm{~g}, 20.6 \mathrm{mmol})$ and refluxed for $30 \mathrm{~min}$. The excess of $\mathrm{SOCl}_{2}$ was evaporated in vacuo and $4 \mathrm{~g}$ ( $36 \mathrm{mmol})$ of aminoguanidine hydrochloride was added. The solid mixture was heated in an oil bath at $180^{\circ} \mathrm{C}$ for $2 \mathrm{~h}$. Then a solution of $10 \mathrm{~g}$ of sodium hydroxide in $40 \mathrm{~mL}$ of water was added and the reaction mixture was refluxed for another $2 \mathrm{~h}$. The precipitate was filtered off and washed with water, ethanol, acetic acid, and water again.

Step 4

$3.288 \mathrm{~g}\left(\max 12.3 \mathrm{mmol}\right.$ of $\mathrm{NH}_{2}$ group) of step 3 product was suspended in $25 \mathrm{~mL}$ of acetic acid and $6.15 \mathrm{~mL}(5.52 \mathrm{~g}$, $37 \mathrm{mmol}$ ) of triethyl orthoformate and $2.4 \mathrm{~g}(37 \mathrm{mmol})$ of sodium azide were added. The mixture was stirred and heated in a water bath for $10 \mathrm{~h}$. The precipitate was filtered off, washed with water, ethanol, and water again.

\subsection{Sorption studies}

$0.1 \mathrm{~g}$ of the properly prepared sorbent was flooded with $25 \mathrm{~mL}$ of the solution containing metal ions in the concentration of $1 \pm 5 \% \mathrm{mg} \cdot \mathrm{L}^{-1}$ (unless other specified in the studies of extraction rate of metal ions depending on the initial concentrations) of each. Sorption of the metal ions was carried out at room temperature for $30 \mathrm{~min}$ under magnetic stirring. The solution was filtered through a filter paper. A stock solution of the metal ions was used as a reference solution at atomic emission spectroscopy measurements.

\section{Results and discussion}

\subsection{Synthesis}

The first and the most crucial thing that is needed to mention is that the methods of determination of completion of each synthesis step in the modification of Merrifield resin are not exhaustive. As the resin can- not be dissolved in any of widely used solvents, no methods involving analysis of a solution can be applied in this case. The determination of heavy atoms content was performed via XRF analysis, which does not indicate the presence or quantity of elements of the first two periods. Another method that is widely used to prove the conversion of reactants to products in the field of polymers is IR-spectrometry, which is not a quantitative method of analysis in our case. The stages of the synthesis involve the formation of 1,2,3-, 1,2,4-triazole and tetrazole cycles, which have close values of energy for the vibrations [14], and that also made the characterization of each step product hard. Nevertheless, our goal is not to seek for quantitative conversion of in every modification step but to achieve reproducible results for the sorption of metal ions for the final product.

As the conversion is not $100 \%$ for any of the reaction steps, it should be clear that the polymer product of each step contains links formed in each of the previous steps that did not react after. For example, the step 3 product has links of the resin containing chloromethyl group 1, azidomethyl group 2, 1,2,3-triazolecarboxylic acid fragment $\mathbf{3}$ and 5-amino-1,2,4-triazole fragment 4.

The first step of Merrifield resin modification included nucleophilic substitution of chlorine atom by azide. The conversion was monitored by IR spectroscopy and X-ray fluorescence (XRF) analysis, which was used for determination of chlorine mass percent. For instance, the presence of the azide group was confirmed by IR-spectroscopy, where it had a narrow absorption band at $\sim 2090 \mathrm{~cm}^{-1}$, while the XRF results showed decreasing of the mass percent of $\mathrm{Cl}$ from $19.2-22.0 \%$ to $1.9-2.3 \%$, that corresponded to the maximum conversion of $91 \%$; the mass percent of other heavy elements detectable by XRF did not change much and could be neglected $(<0.5 \%)$.

The second step involved 1,3-dipolar $[3+2]$-cycloaddition of formed azide-containing links of the resin 2 to propiolic acid $\mathrm{C} \equiv \mathrm{C}$ bond. The formation of the 1,2,3-triazole links 3 was confirmed by IR-spectroscopy, where characteristic bands of triazole fragment at $\sim 1283$ and $\sim 1072 \mathrm{~cm}^{-1}$ were observed. The crude product right after the click reaction had a distinctive reddish color that corresponds to metallic copper and to get rid of it $30 \%$ solution of nitric acid was added which dissolved all the metal. The solution now contained $\mathrm{Cu}(\mathrm{II})$ ions, 


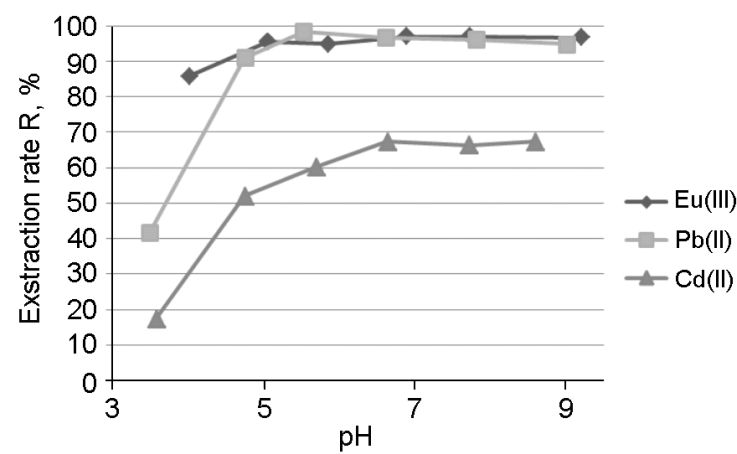

Fig. 2. $\mathrm{Eu}(\mathrm{III}), \mathrm{Pb}(\mathrm{II})$ and $\mathrm{Cd}(\mathrm{II})$ extraction rate dependence on $\mathrm{pH}$.

which can be absorbed by the material we had, and that was confirmed by the XRF analysis. It should be noted, that the presence of plenty of copper ions in the modified resin in this step is the evidence of the strong complexing power of the functional groups we introduced to the substance. To extract the copper ions from the resin an EDTA solution was used, however, the extraction was not complete and XRF analysis showed traces of copper in the product of this step. Additionally, the IR spectroscopy indicated the comparable decrease in the intensity of the azide group peak and the indirect titration showed that the concentration of free carboxyl groups in the resin is around $0.06 \mathrm{mmol} / \mathrm{g}$. The reason for such low result can be the imperfection of the titration procedure which does not consider sterical hindrance of a carboxyl group, the strength of the 1,2,3-triazolecarboxylic acid and probably other factors.

The next step included the formation of $1,2,4$-triazole-containing links 4 in the structure of the resin. The formation was confirmed with IR-spectrum, where an intense characteristic 1,2,4-triazole peak at $\sim 1088 \mathrm{~cm}^{-1}$ appeared. The IR-spectrum of the step 4 product was almost identical to the step 3 product, which meant the conversion of 5 -amino-1,2,4-triazole links 4 to tetrazole links 5 was not extensive. However, step 4 product showed much better quantitative characteristics of metal ions complexation during sorption studies on our next step of research, that gives us a right to assume that another ligand fragment was formed.

\subsection{Testing of complexation dependence} on $\mathrm{pH}$ for step 4 product (aged)

$\mathrm{pH}$ value can affect the metal extraction rate, as the metals are known to form different complexes depending on $\mathrm{pH}$, and this formation is the competing process for the sorption. In addition, $\mathrm{pH}$ can influence the

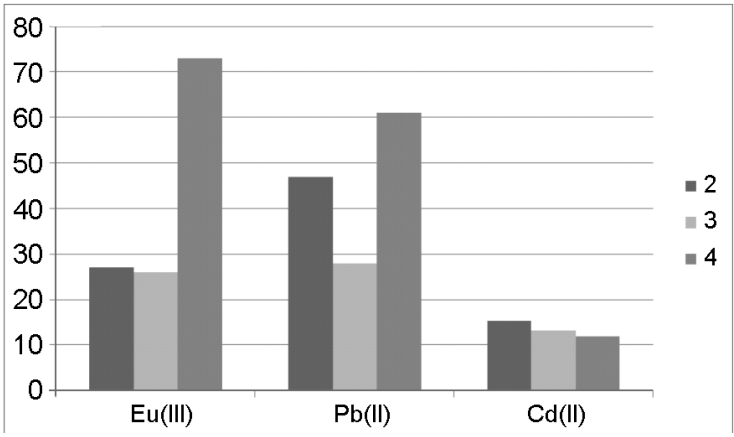

Fig. 3. Extraction rates of $\mathrm{Eu}^{3+}, \mathrm{Pb}^{2+}$ and $\mathrm{Cd}^{2+}$ for products of steps 2-4 of the synthesis.

capacity of the sorbent. The experiments employed $\mathrm{Eu}(\mathrm{III}), \mathrm{Pb}(\mathrm{II})$ and $\mathrm{Cd}(\mathrm{II})$ as model ions and the sorbent 5 of 3 months age were carried out (Fig. 2).

The results show that the extraction rate for each metal has a tendency to increase with the increasing of $\mathrm{pH}$ level. Due to the possible formation of hydroxyl complexes and metal hydroxide precipitates optimum sorption $\mathrm{pH}$ values were chosen to be in the range of 6.5-7.0.

\subsection{Sorption characteristics of synthesis} steps 2-4 products

To examine the change in sorption characteristics of the products which contain 1,2,3-triazole, 1,2,3-triazole and 1,2,4-triazole, and both triazoles and tetrazole links (products of steps 2, 3 and 4, respectively), the extraction rates of $\mathrm{Eu}(\mathrm{III}), \mathrm{Pb}(\mathrm{II})$ and $\mathrm{Cd}(\mathrm{II})$ were measured (Fig. 3). The experiments were carried out at optimal $\mathrm{pH}$ values close to those determined in section 3.2. The age of each sorbent is around 1 week.

The products of all steps show the lowest affinity for cadmium ions, barely extracting them at all. Lead ions are poorly complexed only with step 3 product, and moderate with step 2 product and highly by step 4 product, which can be explained by different affinities of lead ions for carboxyl and amino groups. Finally, step 4 product has a great advantage over other products for the extraction of europium ions.

\subsection{Extraction rate trends}

The extraction rates of metal ions were also measured in terms of their dependence on the initial concentration of the metal. Step 4 product was used as the only sorbent towards $\mathrm{Eu}(\mathrm{III}), \mathrm{Pb}(\mathrm{II})$ and $\mathrm{Cd}(\mathrm{II})$. Their concentration varied from 1 to $20 \mathrm{mg} / \mathrm{L}$ (Table 1).

$\mathrm{Pb}(\mathrm{II})$ and $\mathrm{Cd}(\mathrm{II})$ ions have their rates of extraction decreasing as the concentration 
I.M.Zviagin et al. / Merrifield resin-linked ...

Table 1. Extraction rate dependence on the concentration of metal ions

\begin{tabular}{||c|c|c|c|c|c|c|c|c||}
\hline \multicolumn{3}{|c|}{$\mathrm{Eu}(\mathrm{III})$} & \multicolumn{3}{c|}{$\mathrm{Pb}(\mathrm{II})$} & \multicolumn{3}{c||}{$\mathrm{Cd}(\mathrm{II})$} \\
\hline $\begin{array}{c}c_{\text {inj }}, \\
\mathrm{mg} / \mathrm{L}\end{array}$ & $\begin{array}{c}c_{\text {found }}, \\
\mathrm{mg} / \mathrm{L}\end{array}$ & $\begin{array}{c}R, \\
\%\end{array}$ & $\begin{array}{c}c_{\text {inj }}, \\
\mathrm{mg} / \mathrm{L}\end{array}$ & $\begin{array}{c}c_{\text {found }}, \\
\mathrm{mg} / \mathrm{L}\end{array}$ & $\begin{array}{c}R, \\
\%\end{array}$ & $\begin{array}{c}c_{\text {inj }}, \\
\mathrm{mg} / \mathrm{L}\end{array}$ & $\begin{array}{c}c_{\text {found }}, \\
\mathrm{mg} / \mathrm{L}\end{array}$ & $\begin{array}{c}R, \\
\%\end{array}$ \\
\hline 1 & 0.008 & $>99$ & 1 & 0.045 & 95.5 & 1 & 0.046 & 95.40 \\
2 & 0.005 & $>99$ & 2 & 0.093 & 95.4 & 2 & 0.25 & 87.50 \\
5 & 0.005 & $>99$ & 5 & 1.1 & 77.4 & 5 & 2.5 & 49.40 \\
10 & 0.005 & $>99$ & 10 & 2.6 & 73.9 & 10 & 6.2 & 37.70 \\
15 & 0.005 & $>99$ & 15 & 4.7 & 68.8 & 15 & 10.4 & 30.67 \\
20 & 0.005 & $>99$ & 20 & 8.1 & 59.6 & 20 & 13.9 & 30.30 \\
\hline
\end{tabular}

Table 2. Parameters of Langmuir adsorption equation

\begin{tabular}{|c|c|c||}
\hline Metal & $q_{\max }, \mathrm{mmol} / \mathrm{g}$ & $K_{L}, \mathrm{~L} / \mathrm{mmol}$ \\
\hline $\mathrm{Pb}(\mathrm{II})$ & 0.021 & 62 \\
$\mathrm{Cd}(\mathrm{II})$ & 0.017 & 21 \\
\hline
\end{tabular}

rises. The obtained dependences were described with non-linear Langmuir sorption model using OriginLab Origin 9.0 software. The derived parameters (maximum adsorption $\mathrm{q}_{\max }$, Langmuir constant $K_{L}$ ) of the Langmuir equation are summarized in Table 2.

To determine if anions can interfere with extracting process by the sorbent, forming ionic pairs or complexes with the cations, sorption studies were carried out with step 4 product with the age of 2 months. As a model cation $\mathrm{Eu}(\mathrm{III})$ was chosen, as model anions $-\mathrm{Cl}^{-}, \mathrm{HCO}_{3}{ }^{-}$and $\mathrm{SO}_{4}{ }^{2-}$. $\mathrm{pH}$ level was not regulated but only monitored. The anions were present in the solution at the same time and of the same concentration (Fig. 4).

The general trend follows the hypothesis: the competing process of anionic complexes formation interferes with the extraction of the metal ions with the sorbent. The greater the concentration of the ions, the lower the extraction rate for the sorbent.

To test if the developed sorbent is applicable for extraction of metal ions from not distilled but natural water, the sorption studies were carried out. Extraction rates for model cations $\mathrm{Eu}(\mathrm{III}), \mathrm{Pb}(\mathrm{II})$ and $\mathrm{Cd}(\mathrm{II})$ were measured (Table 3), and the water came from the spring on the SSI "ISC" NASU territory (Table 4). The age of the sorbent is 3 months.

Europium and lead ions are extracted to a great extent and the sorbent is applicable in the media where the main pollutants are the ions of these metals. However, the modified resin does not show affinity for cadmium ions and can't be used for water purification that is polluted with $\mathrm{Cd}(\mathrm{II})$ salts.

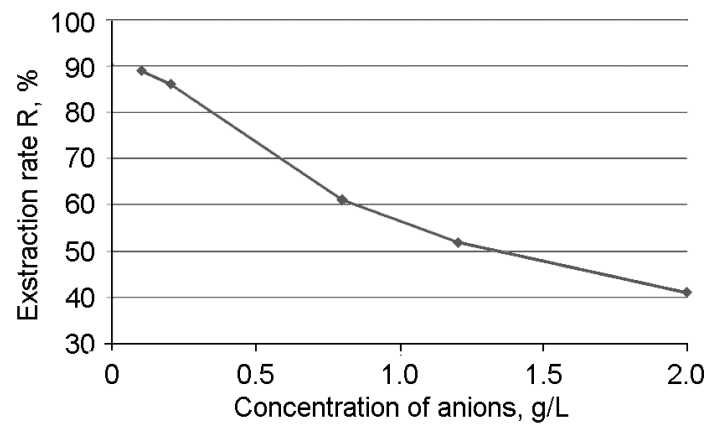

Fig. 4. Anion concentration extraction rate dependence.

\section{Conclusions}

The modification of Merrifield resin lead to consecutive formation of 1,2,3-triazole, 1,2,4-triazole and tetrazole cycles which were covalently bound to the polymer. However, the product of each step of modification contained polymer links that were products of precious steps of synthesis, including azidomethylpolystyrene and even the starting resin links of chloromethylpolystyrene, the presence of which was confirmed by IR spectroscopy. The general trend shows that the greatest extraction rate is possessed by the product of the last step, which lead to the formation of tetrazole fragment, and this fact is another evidence of successful formation of the tetrazole. Besides, the tendency in extraction rate increase indicates that it is directly influenced by the number of polyazole fragments per unit of mass of the sorbent.

The obtained modified polymer was tested for its ability to extract metal ions depending on different changing factors, such as $\mathrm{pH}$ of the medium, the concentration of metal cations and the concentration of different anions that can interfere with the sorption process. The $\mathrm{pH}$ value was measured to assure the largest extraction rate and it was found that optimal $\mathrm{pH}$ values were different for different metals, and 
Table 3. Extraction rates of metal ions from natural water

\begin{tabular}{|c|c|c||}
\hline Element & $\begin{array}{c}\text { Extraction rate } \\
R, \%\end{array}$ & $\mathrm{pH}$ \\
\hline $\mathrm{Eu}(\mathrm{III})$ & $60 \pm 12$ & 7.0 \\
$\mathrm{~Pb}(\mathrm{II})$ & $80 \pm 13$ & 6.8 \\
$\mathrm{Cd}(\mathrm{II})$ & $14 \pm 2$ & 6.8 \\
\hline
\end{tabular}

$\mathrm{Pb}(\mathrm{II})$ ions had greater affinity for the sorbent in more acidic medium, which can be explained by the fact that $\mathrm{Pb}(\mathrm{II})$ forms insoluble hydroxide precipitate at lower $\mathrm{pH}$ levels. For double charged cations the sorbent quickly reaches saturation point as the concentration of the cations increase, and the saturation level for europium ions is higher. The sorbent is still able to extract metal ions from the water when such ions as hydrogen carbonate, chloride and sulfate are present, though its capacity significantly lowers. As the sorbent does not dissolve in water, it is suitable for application for natural waters.

\section{References}

1. E.A.Popova, R.E.Trifonov, V.A.Ostrovskii, $A R K I V O C, I, 45$ (2012).

2. B.M.J.M.Suijkerbuijk, B.N.H.Aerts, H.P.Dijkstra et al., J.Chem.Soc.Dalt.Trans., 0, 1273 (2007).

3. S.Zaydoun, M.S.Idrissi, A.Zrineh et al., Polyhedron, 14, 1477 (1995).
Table 4. Natural spring water contents

\begin{tabular}{|c|c|c|c||}
\hline \hline Ion & $\begin{array}{c}\text { Concentration, } \\
\mathrm{mg} / \mathrm{L}\end{array}$ & Ion & $\begin{array}{c}\text { Concentration, } \\
\mathrm{mg} / \mathrm{L}\end{array}$ \\
\hline $\mathrm{Ca}^{2+}$ & 100 & $\mathrm{Fe}^{3+}$ & 0.1 \\
$\mathrm{Mg}^{2+}$ & 30 & $\mathrm{Cl}^{-}$ & 44 \\
$\mathrm{Na}^{+}$ & 120 & $\mathrm{NO}_{3}^{-}$ & 12 \\
$\mathrm{~K}^{+}$ & 11 & $\mathrm{SO}_{4} 2^{-}$ & 144 \\
$\mathrm{Sr}^{2+}$ & 1 & $\mathrm{HCO}_{3}^{-}$ & 420 \\
\hline
\end{tabular}

4. G.Aromi, L.A.Barrios, O.Roubeau, P.Gamez, Coordination Chemistry Reviews, Elsevier Pub. Co (2011).

5. D.A.Safin, A.P.Railliet, K.Robeyns et al., New J.Chem., 41, 6210 (2017).

6. Y.Boland, P.Hertsens, J.Marchand-Crynaert, Y.Garcia, Synthesis (Stuttg), 9, 1504 (2006).

7. C.Pettinari, A.Tabacaru, S.Galli, Coord.Chem. Rev., 307, 1 (2016).

8. Y.E.Alekseev, Y.A.Zhdanov, T.P.Sudareva, Russ.J.Gen.Chem., 75, 1879 (2005).

9. S.V.Khimchenko, T.A.Blank, K.N.Belikov et al., Functional Materials, 24, 706 (2017).

10. S.Arseniyadis, A.Wagner, C.Mioskowski, Tetrahedron Lett., 43, 9717 (2002).

11. J.E.Hein, V.V.Fokin, Chem.Soc.Rev., 39, 1302 (2010).

12. E.V.Tarasova, A.V.Chernysheva, E.V.Konenko, V.M.Chernyshev, in: Materialy XIV Molodezhnoy Konferentsii po Organicheskoy Himii, Yekaterinburg, Russia (2011), p.499.

13. P.N.Gaponik, V.P.Karavai, Y.V.Grigor'ev, Chem. Heterocycl. Compd., 21, 1255 (1985).

14. F.Billes, H.Endredi, G.Keresztury, J.Mol. Struct. THEOCHEM, 530, 183 (2000). 